\title{
Sistem Informasi Penjadwalan Mata Pelajaran Pada Sma Negeri 02 Tebing Tinggi Dengan Menggunakan Metode Genetika Berbasis Web
}

\author{
Ryandi Apriando Fajar \& Kurniati \\ Teknik Informatika, Universitas Bina Darma, Palembang, Indonesia \\ Email: ryandiapriandofajar@gmail.com
}

\begin{abstract}
The subject scheduling information system is one way to overcome the optimization problem determined by the institution where the schedule is used, namely at SMA Negeri 2 Tebing Tinggi, Empat Lawang Regency, South Sumatra Province. The software was tested on several different data groups using the genetic algorithm method. The results obtained are helping to arrange automatic scheduling of subject scheduling. Based on the test results of the subject scheduling information system software at SMA Negeri 2 Tebing Tinggi using the Black box and the usability of the overall test summary results are said to be good. So that with the subject scheduling system at SMA Negeri 2 Tebing Tinggi, Empat Lawang Regency, South Sumatra Province, it can be more efficient and even better in compiling subject schedules.
\end{abstract}

Keywords: Information System, Scheduling, Genetics, PHP

\section{Pendahuluan}

Penjadwalan mata pelajaran merupakan kegiatan yang sangat penting untuk dapat terlaksananya sebuah proses belajar mengajar yang baik bagi sebuah lembaga pendidikan seperti perguruan tinggi. Sebuah penjadwalan yang baik adalah sebuah penjadwalan yang dapat dilakukan oleh seluruh pihak yang terkait dalam kegiatan belajar mengajar, Pada penelitian ini, peneliti melakukan penelitian pada lembaga pendidikan di SMA Negeri 2 Tebing Tinggi Empat Lawang yang beralamat di Jalan Brigjen Yahya Bahar, Jaya Loka, Kec. Tebing Tinggi, Kabupaten Empat Lawang, Sumatera Selatan. Pada SMA Negeri 2 Tebing Tinggi ini masih menggunakan sistem penjadwalan mata pelajaran manual yaitu masih mencatat menggunakan excel. Hal ini menyebabkan sulitnya menentukan jadwal mata pelajaran yang tepat sesuai dengan kesiapan waktu mereka dan lokal yang tersedia, dimana kesiapan waktu mengajar bagi pendidik baik itu guru sangatlah terbatas.(Nugraha and et al, 2022).

Algoritma Genetika merupakan suatu metode heuristik yang dikembangkan berdasarkan prinsip genetika dan proses seleksi alamiah Teori Evolusi Darwin. Dalam Teori Evolusi Darwin, suatu individu tercipta secara acak kemudian berkembang biak melalui proses reproduksi sehingga terbentuk sekumpulan individu sebagai suatu populasi. Untuk permasalahan penjadwalan perawat, algoritma genetika dapat digunakan sebagai metode pengembangan sistem yang dapat membantu mengoptimalkan daftar jaga perawat. Permasalahan dengan model matematika yang kompleks atau bahkan sulit dibangun dapat diselesaikan menggunakan algoritma genetika (Assagaf and et al, 2018). Dengan menggunakan algoritma Genetika serta dirancangnya sebuah sistem infomasi penjadwalan dengan bahasa pemrograman PHP serta Mysql sebagai media penyimpanan database, diharapkan dapat membantu pihak pihak sekolah yang dalam hal ini program studi teknik informatia menyusun penjadwalan mata pelajaran yang lebih baik dan efisien terhadap setiap guru yang akan mengajar. Sehingga menggurangi terjadinya resiko jadwal yang berbenturan dengan jadwal lain serta dapat membuat jadwal-jadwal yang lebih teratur dan efisien (Paranduk and et al, 2018) 
Masalah-masalah penjadwalan yang terjadi di SMA Negeri 2 Tebing Tinggi Empat Lawang tersebut, dapat diminimalisir kan dengan perhitungan waktu yang tepat. Selain itu, juga mempertimbangkan seluruh aspek yang berkaitan dengan kegiatan belajar mengajar sekolah tersebut, dengan adanya masalah penjadwalan mata pelajaran di SMA Negeri 2 Tebing Tinggi, maka dibutuhkan sebuah solusi pemecah masalah yang ada, yaitu bagaimana memecahkan masalah yang ada dalam penjadwalan dengan suatu metode agloritma yaitu Genetic Algorithm (Algoritma Genetika). (Fahmi, 2015)

\section{Tinjauan Literatur}

\subsection{Sistem Informasi}

Menurut (Indrajani, 2014) Sistem informasi merupakan kombinasi terartur apa pun dari orang-orang, hardware, software, jaringan komunikasi, dan sumber daya data, yang mengumpulkan, mengubah, dan menyebarkan informasi dalam sebuah organisasi. Sistem informasi juga adalah sekelompok elemen yang saling berhubungan atau berinteraksi hingga membentuk satu-kesatuan.

\subsection{Algoritma Genetika}

Algoritma genetika merupakan suatu algoritma pencarian metaheuristik yang berdasar pada mekanisme seleksi alam dan operasi genetika guna diperolehnya suatu solusi. Solusi yang dihasilkan, ditentukan berdasarkan nilai parameter dan operator yang digunakan. Penentuan cara kerja dari masing-masing operator yaitu operator seleksi, Crossoverdan mutasi, dapat diketahui dengan menggunakan teori Schemata.(Khairu et al., 2020).

\section{Metode Penelitian}

Metode penelitian yang digunakan adalah metode analisis deskriptif dengan pendekatan kuantitatif artinya penelitian yang dilakukan adalah menekankan analisanya pada data-data numerik (angka), yang bertujuan untuk mendapatkan gambaran yang jelas mengenai suatu keadaan berdasarkan data yang diperoleh dengan cara menyajikan, mengumpulkan dan menganalisis data tersebut sehingga menjadi informasi baru yang dapat digunakan untuk menganalisa mengenai masalah yang sedang diteliti. "Metode deskriptif adalah metode yang digunakan untuk menggambarkan analisis suatu hasil penelitian tetapi tidak digunakan untuk membuat kesimpulan yang lebih luas"

\subsection{Metode Pengembangan Sistem}

Untuk metode pengembangan software pada penelitian ini, peneliti menggunakan model Agile dan menggunakan metode pengembangan software Extreme Programming (XP). Menurut Kuda Nageswara Rao, G. Kavita Naidu, Praneeth Chakka pada jurnal "A Study of the Agile Software Development Methods, Applicability and Implications in Industry", Metode Agile merupakan model yang fokus untuk pengembangan solusi yang lebih cepat dan efisien. Metode pengembangan software yang ada pada model agile yaitu: Extreme Programming (XP), Dynamic Software Development Method (DSDM), Scrum, dan Crystal. Berikut adalah tabel deskripsi dan kelebihan dari metode pengembangan software yang ada pada model Agile: [5] 


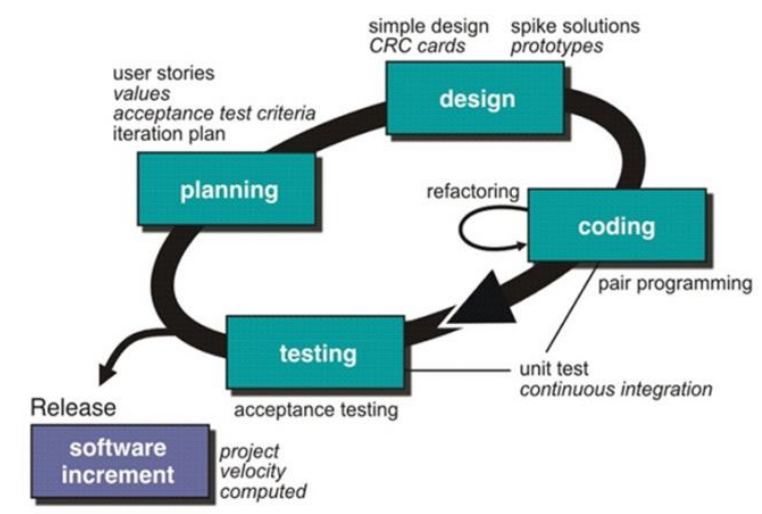

Sumber Gambar: http://machlizadevi.blog.binusian.org/files/2014/04/xp.jpg

Gambar 1. Model Extreme Programming

Tahapan - tahapan model Extreme Programming:

1. Planning, Dalam tahap ini dikumpulkan kebutuhan awal user atau dalam XP disebut user stories. Hal ini dibutuhkan agar pengembang mengerti bisnis konten, kebutuhan output sistem, dan fitur utama dari software yang dikembangkan. Tahapan ini untuk menganalisa kebutuhan dari sistem tersebut untuk dapat digunakan sesuai dengan user requirement atau user stories. (Saifudin and et al, 2019)

2. Design, Desain dari sistem pada penelitian ini digambarkan dengan model UML berupa use case diagram, activity diagram, dan relation table. Pembuatan desain pada XP tetap mengedepankan prinsip Keep it Simple (KIS). Desain disini merupakan representasi dari sistem guna mempermudah pengembang dalam membangun sistem. Desain ini dimaksudkan untuk mempermudah pengembangan sistem nantinya.

3. Coding, Proses melakukan coding system (pengkodean perangkat lunak) oleh Programmer/Software Engineer sesuai dengan planning dan design yang telah dibuat sebelumnya. (Nasril and et al, 2019)

4. Testing, Tahap ini akan menggunakan unit test yang sebelumnya telah dibuat. Karena pembuatan dari unit test adalah pendekatan utama dari XP. Dalam melakukan pengujian, penulis menggunakan 2 teknik pengujian yaitu pengujian white box. Pada tahap pengujian black box, dilakukan pengujian setiap unit test, maksudnya melakukan pengujian integrasi antara input dan hasil output yang sesuai semestinya terjadi. (Pratama, 2014)

\subsection{Desain}

Tahap ini adalah pembuatan desain secara umum untuk selanjutnya dikembangkan kembali. Dalam hal ini menggunahkan uml untuk membuat pemodelan seperti Usecase Diagram, Activity Diagram, dan Class Diagram.

\section{A. Usecase diagram}




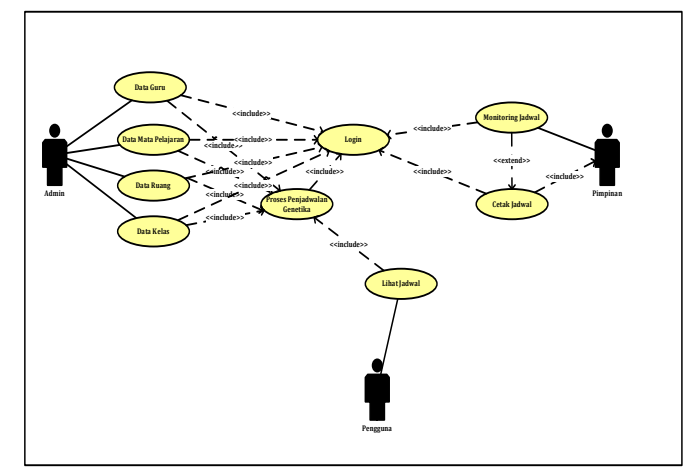

Gambar 2. Usecase Diagram

Didalam usecase tersebut terdapat dua aktor yaitu admin, dan pengguna yang melakukan aktivitas dalam sistem, admin sebagai pemilik hak akses penuh sama berfungsi sebagai admin sistem dapat mengelola seluruh proses penjadwalan, sedangkan pengguna dapat melihat jadwal dan mencetak jadwal Mata Pelajaran berikut penjelasannya sebagai berikut:

\section{B. Activity Diagram}

Setelah rancangan usecase diagram dibuat maka selanjutnya adalah rancangan dari Activity Diagram yaitu rancangan yang akan menjabarkan rancangan pada isi Usecase diagram sebelumnya, untuk rancangannya sebagai berikut.

1. Activity Diagram Data Jadwal

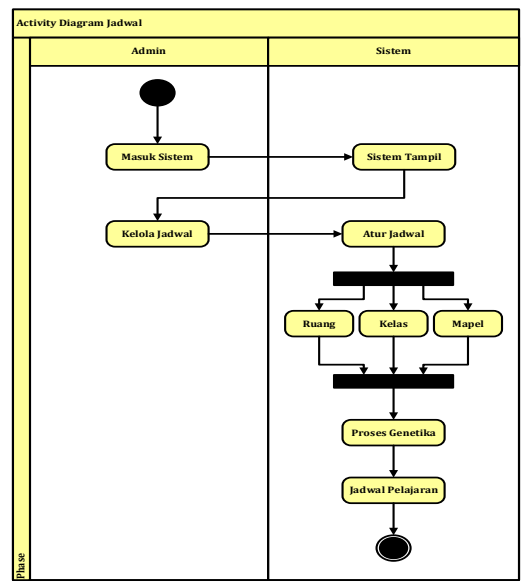

Gambar 3. Activity Diagram Data Jadwal

Dari Gambar. 3 diatas menunjukan kegiatan dalam pengelolahan data jadwal Mata Pelajaran pada SMA Negeri 2 Tebing Tinggi, yang berdasarkan ruang, kelas, dan Mata Pelajaran

2. Activity Diagram Guru 


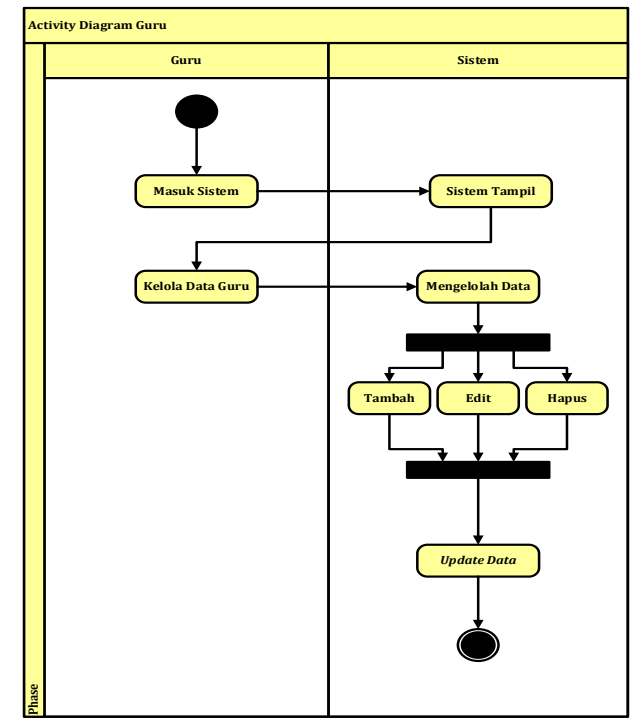

Gambar 4. Activity Diagram Guru

Dari gambar 4 diatas menunjukan Activity Diagram guru yang prosesnya di kelola oleh admin, pada proses penelolahan data tersebut terdapat fungsi tambah, edit dan hapus data guru.

3. Activity Diagram Jadwal Mata Pelajaran

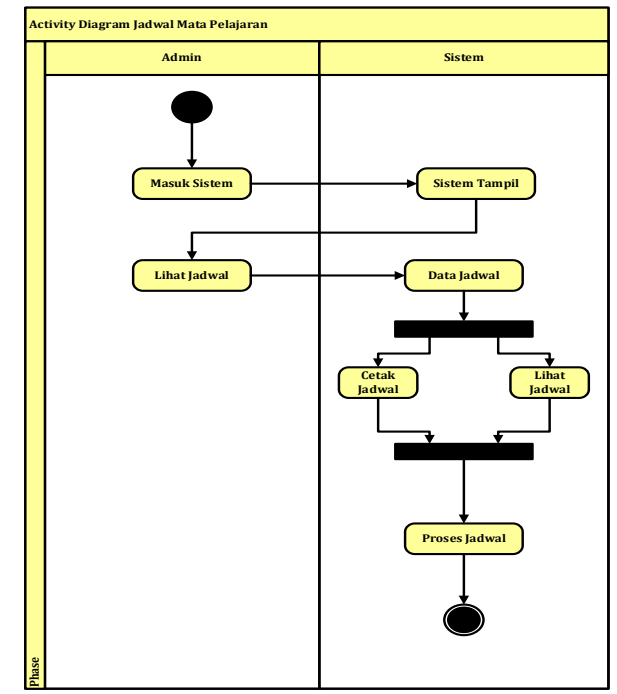

Gambar 5. Activity Jadwal Mata Pelajaran

Dari gambar 5 menunjukan Activity Diagram kelola data jadwal mata pelajaran yang prosesnya di kelola oleh admin, pada proses pengelolahan data tersebut terdapat fungsi lihat dan cetak jadwal Mata Pelajaran.

\section{Hasil dan Pembahasan}

Sistem informasi penjadwalan mata pelajaran pada SMA Negeri 2 Tebing Tinggi dengan menggunakan metode genetika berbasis web dengan menggunakan sistem ini pengaturan penjadwalan mata pelajaran khususnya pada SMA Negeri 2 Tebing Tinggi menjadi lebih baik lagi, berikut hasil dari pembangunan sistem informasi penjadwalan mata pelajaran yang telah dibangun.

1. Sistem informasi penjadwalan dapat menyusun jadwal mata pelajaran pada SMA Negeri 2 


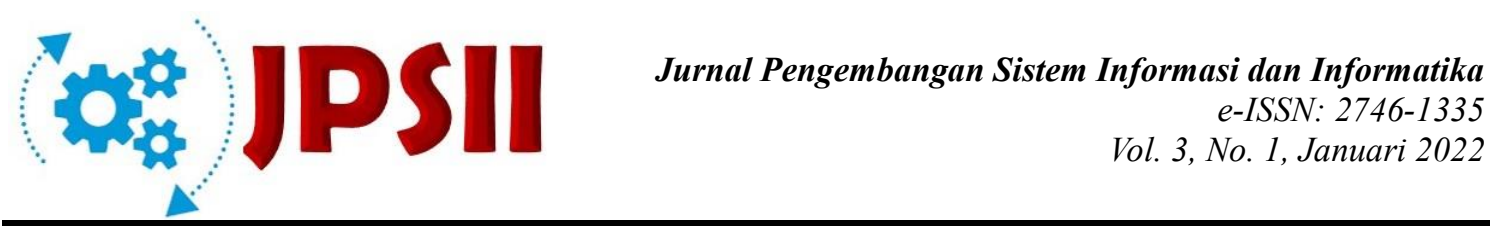

Tebing Tinggi

2. Sistem yang dibangun menggunakan bahasa pemrograman framework Codeignitier

3. Sistem dapat mendata mata pelajaran, guru, kelas dan ruang untuk disusun menjadi jadwal mata pelajaran.

\subsection{Pembahsan Metode Genetika}

Sebelum dilakukan simulasi Algoritma Genetika dalam rangka meyakinkan konsep dan algoritma pemrograman dalam mengembangkan penjadwalan komputasi terdistribusi menggunakan Algoritma Genetika dengan metoda paralelisme tugas, dilakukan representasi kromosom dan simulasi tiap-tiap komponen Algoritma Genetika. Ciri khas Algoritma Genetika memerlukan dua buah variabel yang harus didefinisikan, yaitu, sebuah representasi genetika dari domain solusi, dan sebuah fungsi fitness untuk mengevaluasi domain solusi.

Berikut merupakan data mata pelajaran yang sudah dimasukan kedalam sistem informasi penjadwalan.

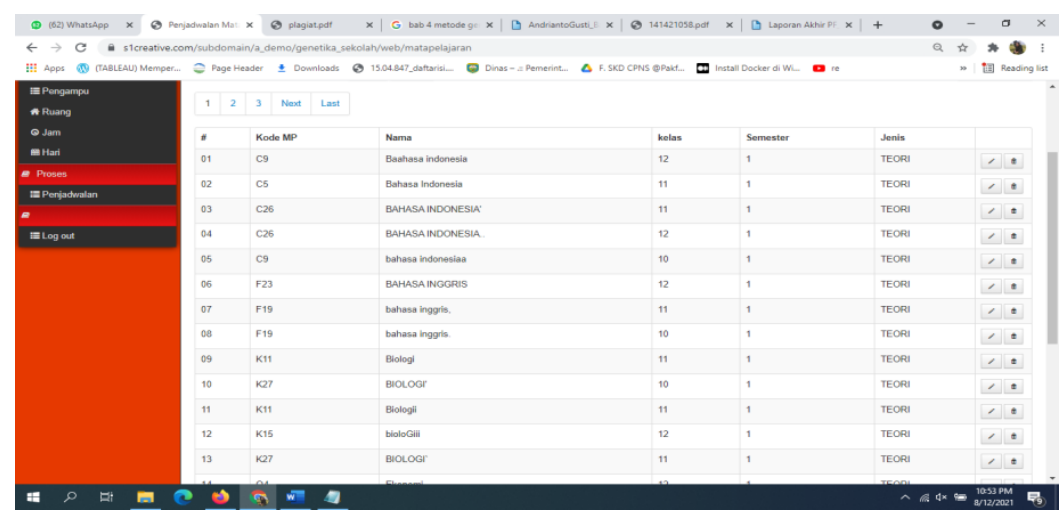

Gambar 6. Data Mata Pelajaran

Berdasarkan gambar diatas maka proses selanjutna adalah mengelola data mata pelajaram tersebut dengan Algoritma Genetika. Algoritma ini sendiri terdiri beberapa komponen proses, proses inisialisasi populasi, seleksi individu dengan menghitung nilai fitness setiap individu, proses crossover jika syarat terjadi crossover terpenuhi, proses mutasi jika syarat mutasi terpenuhi, dan kembali ke proses seleksi individu dari populasi yang baru hasil dari crossover dan mutasi atau terminasi setelah hasil optimasi (solusi) telah diperoleh Pseudo-code algoritma dari Algoritma Genetika adalah sebagai berikut:

1. Pilih populasi awal yaitu jumlah mata pelajaran, guru dan ruangan

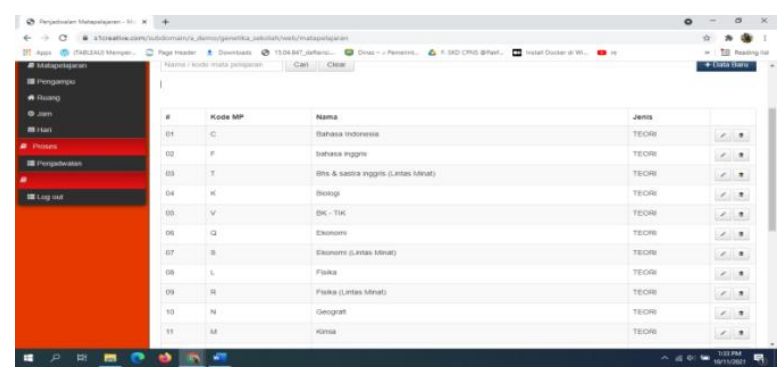

Gambar 7. Proses memasukan Populasi

2. Hitung nilai fitness tiap-tiap individu dalam populasi dalam hal ini ialah data mata pelajaran, 


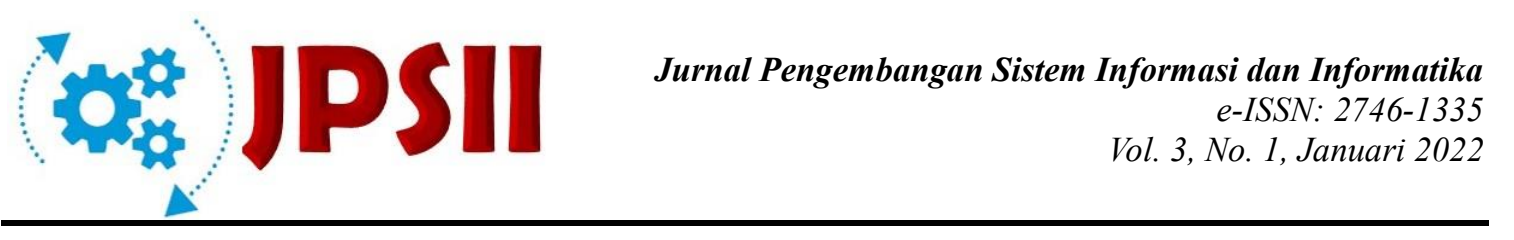

ruangan dan guru.

\subsection{Pembahasan Interface}

Pada bagian ini akan membahas tentang Interface dari sistem informasi penjadwalan yang dibangun, dari Interface yang ditampilkan akan dijelaskan bagaimana cara sistem informasi penjadwalan tersebut bekerja sesuai dengan kebutuhannya.

\section{A. Tampilan Login}

Pada bagian ini merupakan tampilan dari gambaran pada halaman login yang ada pada Sistem informasi penjadwalan mata pelajaran pada SMA Negeri 2 Tebing Tinggi dengan menggunakan metode genetika berbasis web.

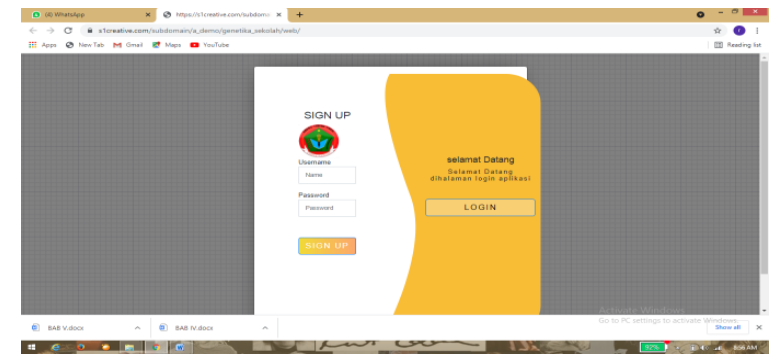

Gambar 8. Tampilan Login

B. Tampilan Dashboard Sistem

Halaman ini akan menampilkan halaman awal setelah login kedalam sistem dan menampilkan informasi data, didalam menu ini dapat memaukan data-data seperti data penjadwalan, mata pelajaran, guru serta ruangan yang akan disusun oleh sistem dalam penyusunan jadwal mata pelajaran pada Sistem informasi penjadwalan mata pelajaran pada SMA Negeri 2 Tebing Tinggi dengan menggunakan metode genetika berbasis web.

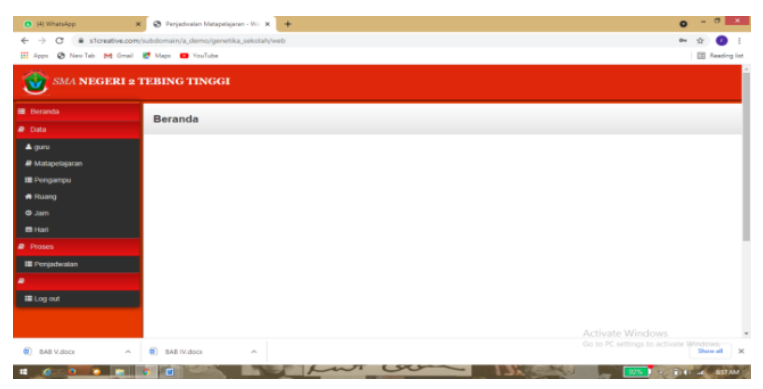

Gambar 9. Dashboard Sistem Informasi

C. Tampilan Data Guru

Berikut merupakan tampilan dari gambaran data guru yang telah dibangun pada sistem penjadwalan mata pelajaran SMA Negeri 2 Tebing Tinggi, pada tampilan ini akan menampilkan data guru serta dilengkapi fitur untuk mengupdate data serta menghapus data guru Sistem informasi penjadwalan mata pelajaran pada SMA Negeri 2 Tebing Tinggi dengan menggunakan metode genetika berbasis web. 

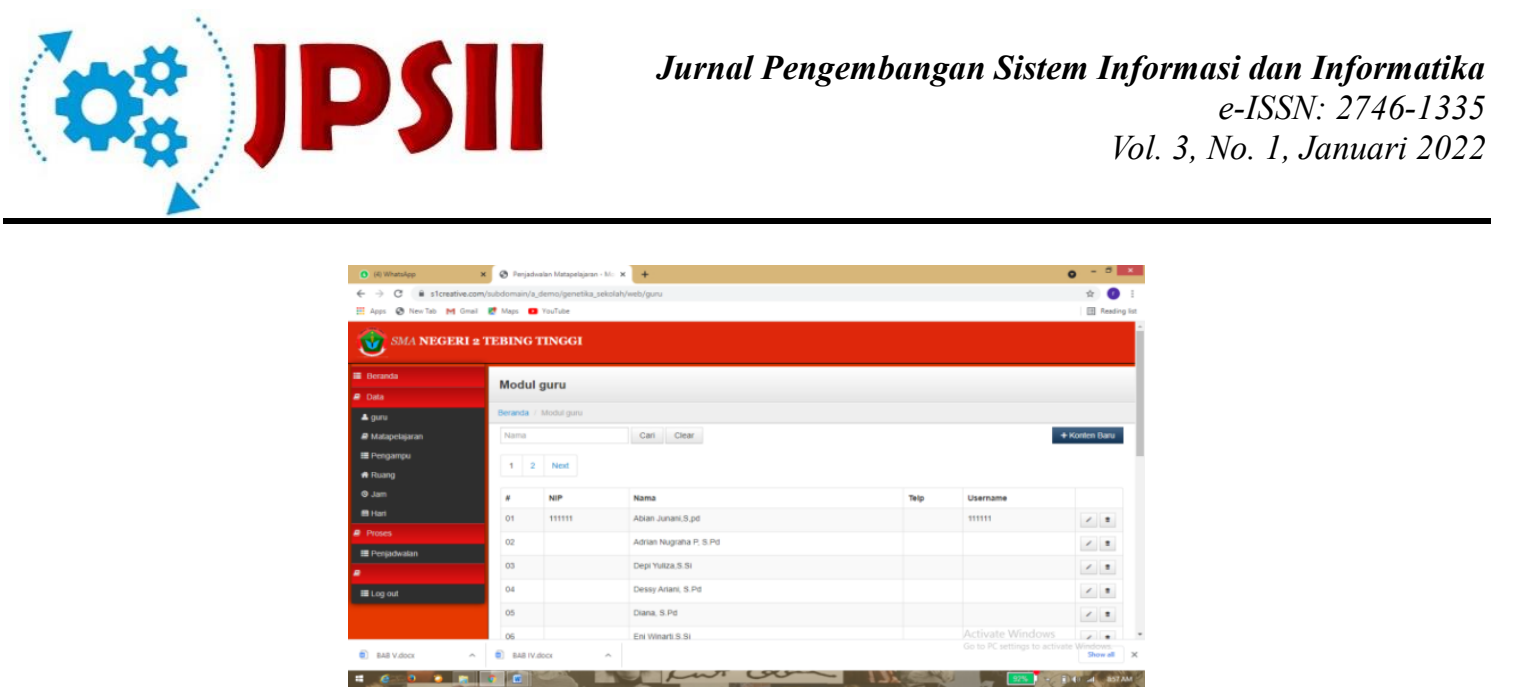

Gambar 10. Tampilan Data Guru

Dalam tampilan ini terdapat id identitas guru, nama, kode dan alamat setiap guru yang sudah dilakukan pendataan oleh admin sebelumnya dan juga dalam tabel menu ini juga dibantu dengan tombol aksi edit dan hapus dalam sistem informasi penjadwalan mata pelajaran pada SMA Negeri 2 Tebing Tinggi.

D. Tampilan Data Mata pelajaran

Pada halaman ini menampilkan tampilan dari gambar data-data mata pelajaran yang telah dimasukan oleh admin kedalam sistem penjadwalan mata pelajaran SMA Negeri 2 Tebing Tinggi

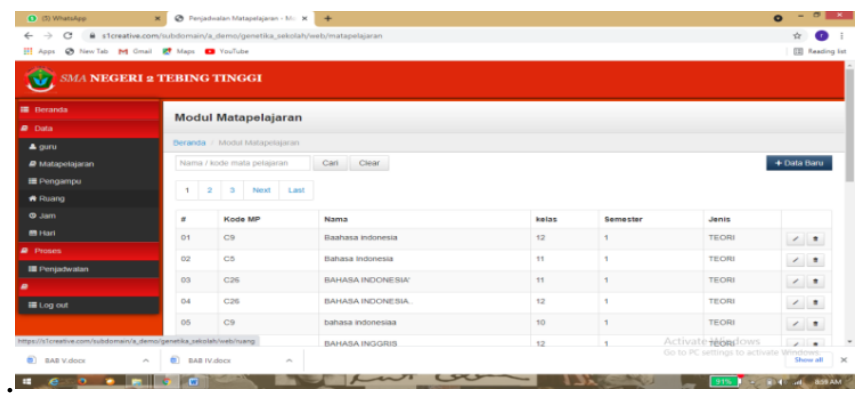

Gambar 11. Tampilan Data Mata pelajaran

Halaman ini menampilkan data mata pelajaran yang dikelola oleh administrator sistem informasi penjadwalan. Hak akses yang dimiliki administrator sistem informasi penjadwalan adalah (create, update, and delete) pada Sistem informasi penjadwalan mata pelajaran pada SMA Negeri 2 Tebing Tinggi dengan menggunakan metode genetika berbasis web.

\section{E. Laporan Data Excel}

Berikut ini merupakan tampilan dari hasil laporan berbentuk excel yang berisi data jadwal mata pelajaran yang sudah di susun dengan algoritma genetika dari Sistem informasi penjadwalan mata pelajaran pada SMA Negeri 2 Tebing Tinggi dengan menggunakan metode genetika berbasis web. 


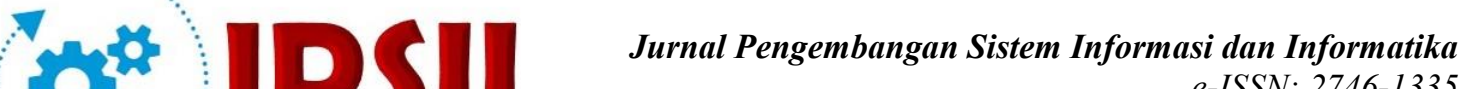

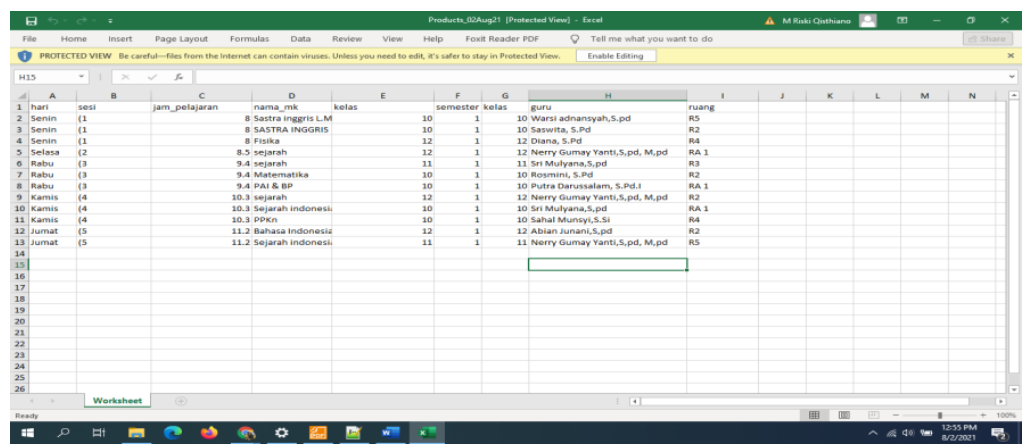

Gambar 12 Tampilan Laporan Excel

\section{Kesimpulan}

Pada tahap ini merupakan tahapan akhir dari hasil penelitian yang berjudul sistem informasi penjadwalan mata pelajaran pada SMA Negeri 2 Tebing Tinggi Dengan menggunakan metode genetika berbasis web. Pada tahapan ini akan merangkum hasil dari penelitian di SMA Negeri 2 Tebing Tinggi. Berikut hasil dari penelitian. Sistem informasi telah dibangun sesuai dengan Sistem informasi penjadwalan mata pelajaran pada SMA Negeri 2 Tebing Tinggi. Sistem informasi penjadwalan mata pelajaran dapat meyusum jadwal otomatis dengan algoritma genetika. Sistem informasi Penjadwalan mata pelajaran dapat menampilkan informasi jadwal mata pelajaran yang sudah disusun. Sistem informasi Penjadwalan mata pelajaran menghasilkan laporan jadwal mata pelajaran dan dapat dicetak dengan format excel. Dari hasil pengujian menggunakan black box, hasil rangkupan pengujian dikatakan baik. Dan dari hasil pengujian menggunakan usability testing yang mengambil responden sebanyak 30 responden, sistem dapat dijalankan dengan baik.

\section{Referensi}

Y. S. Nugraha and et al, "Implementasi Algoritma Genetika pada Perancangan Aplikasi Penjadwalan Instalasi Antivirus Berbasis Website menggunakan Metode Waterfall," Jurnal JTIK (Jurnal Teknologi Informasi dan Komunikasi), vol. 6, no. 1, pp. 117-129, 2022.

A. Assagaf and et al, "Membangun Sistem Informasi Penjadwalan Dengan Metode Algoritma Genetika Pada Laboratorium Teknik Informatika Universitas Muhammadiyah Maluku Utara," lkominfo, vol. 1, no. 2, pp. 95-105, 2018.

L. Paranduk and et al, "SISTEM INFORMASI PENJADWALAN MATA KULIAH MENGGUNAKAN ALGORITMA GENETIKA BERBASIS WEB," in Seminar Nasional Aplikasi Teknologi Informasi (SNATi), Yogyakarta, 2018.

M. R. Fahmi, "SISTEM INFORMASI PENJADWALAN MATA PELAJARAN PADA MADRASAH TSANAWIYAH AR ROHMAN KENCONG," Undergraduate thesis, Universitas Muhammadiyah Jember, pp. 1-5, 2015.

Indrajani. (2014), "Database Systems Case Study All in One", Database Systems Case Study All in One, PT Elex Media Komputindo.

Khairu, N., Farikhin and Surarso, B. (2020), "Analisis Pengaruh Operator Genetik pada Algoritma Genetika dan Penerapannya pada Traveling Salesman Problem ( TSP )", Vol. 3 , pp. 1-7.

A. G. P, "SISTEM INFORMASI PENJADWALAN MATA PELAJARAN SEKOLAH 
STUDI KASUS : SMKN 1 KALIWUNGU, KAB. SEMARANG," Jurnal EKSIS , vol. 6, no. 1, pp. 27-34, 2013.

Saifudin and et al, "SISTEM INFORMASI ARSIP SURAT (SINAU) BERBASIS WEB PADAKANTOR DESA KARANGSALAM KECAMATAN BATURRADEN," Evolusi: Jurnal Sains dan Manajemen, vol. 7, no. 2, pp. 15-21, 2019.

Nasril and et al, "PERANCANGAN SISTEM INFORMASI KPI TELEMARKETING PADA PT. BINTANG SERAGAM INDONESIA," JURNAL LENTERA ICT, vol. 5, no. 2, pp. 32-43, 2019.

I. P. A. E. Pratama, Sistem Informasi dan Implementasinya, Bandung: Informatika, 2014.

\section{Copyrights}

Copyright for this article is retained by the author(s), with first publication rights granted to the journal.

This is an open-access article distributed under the terms and conditions of the Creative Commons Attribution license (http://creativecommons.org/licenses/by/4.0/) 